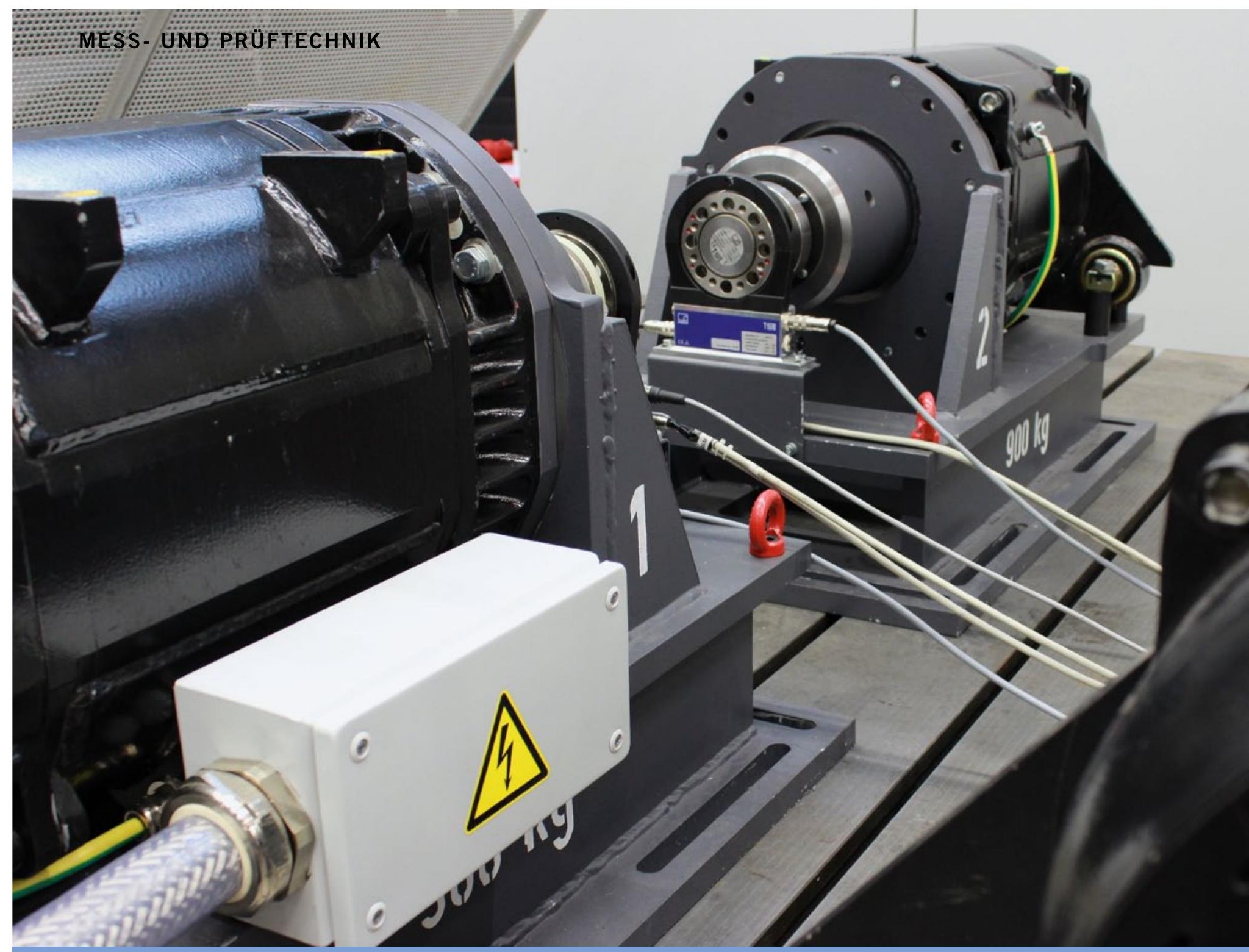

\title{
DYNAMISCHER PRÜFSTAND FÜR ELEKTRISCHE ANTRIEBSSYSTEME
}

Der Trend zur Elektrifizierung von Antriebssystemen in mobilen Arbeitsmaschinen stellt hohe Anforderungen an die Prüfstandstechnik und ihre Infrastruktur. Gerade im Bereich der Verifikation von elektrischen und hybridelektrischen Systemen nehmen die erforderlichen Testapplikationen zu. Um diesen Ansprüchen genügen zu können, wurde am Institut für Fahrzeugsystemtechnik des KIT ein dynamischer Antriebssystemprüfstand geplant und in Betrieb genommen. Der Prüfstand ermöglicht umfangreiche Untersuchungen an mobilen Antriebssystemen und unterstützt die wissenschaftliche Forschung im Anwendungsgebiet der elektrischen und hybridelektrischen Antriebssysteme. 


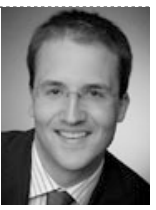

DIPL.-ING. CHRISTIAN POHLANDT

ist akademischer Mitarbeiter am Institut für Fahrzeugsystemtechnik (FAST), Lehrstuhl für Mobile Arbeitsmaschinen des Karlsruher Instituts für Technologie (KIT).

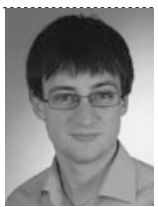

DIPL.-ING. STEFAN HAAG ist akademischer Mitarbeiter am Institut für Fahrzeugsystemtechnik (FAST), Lehrstuhl für Bahnsystemtechnik des Karlsruher Instituts für Technologie (KIT).

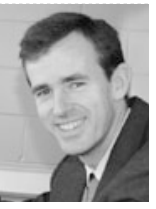

PROF. DR.-ING. MARCUS GEIMER ist Institutsleiter des Instituts für

Fahrzeugsystemtechnik (FAST), Lehrstuhl für Mobile Arbeitsmaschinen des Karlsruher Instituts für Technologie (KIT).

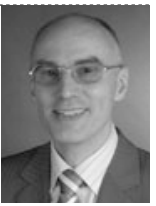

PROF. DR.-ING. PETER GRATZFELD

ist Institutsleiter des Instituts für Fahrzeugsystemtechnik (FAST), Lehrstuhl für Bahnsystemtechnik des Karlsruher Instituts für Technologie (KIT).

\section{MOTIVATION}

Neben der statischen Kennfeldermittlung von individuellen Antriebsstrangkomponenten liegen die Untersuchungen komplexer Antriebssysteme im Fokus der Forschungsaktivitäten. Das Verhalten solcher Systeme unter dynamischen Belastungen ist hierbei von hohem Interesse. Der Zusammenschluss einzelner Teilsysteme aus den Bereichen der elektrischen, mechanischen und hydraulischen Antriebstechnik zu transdisziplinären Systemen erfordert ein universelles, leistungsstarkes Prüfstandskonzept. Die Prüfstandssteuerung, mit standarisierten Schnittstellen zur Kommunikation, muss dabei den hohen Sicherheitsanforderungen des Prüfbetriebes genügen. Eine umfangreiche Messtechnik mit einer hohen Genauigkeit für die zeitsynchrone Erfassung von mechanischen und elektrischen Messgrößen ist unabdingbarer, integraler Bestandteil des gesamten Prüfstandskonzepts, um dynamische Untersuchungen an komplexen elektrischen Antriebssystemen durchführen zu können. Das Ziel eines ganzheitlich systemischen Forschungsansatzes zur Untersuchung von mobilen Antriebssystemen wird durch diese Flexibilität und Variabilität des Prüfstands umfassend unterstützt.

\section{PRÜFSTANDSSPEZIFIKATION}

Die Durchführung von dynamischen Versuchen mit schnellen Last- und Richtungswechseln stellt hohe Anforderungen an die Prüfstandsmaschinen und deren Leistungselektronik, um die erforderlichen Ströme und Spannungen sicher bereitstellen zu können. Das grundlegende Prüfstandskonzept, $\mathbf{0}$, beruht auf einem Gleichspannungszwischenkreis, in den mehrere Wechselrichter zur Versorgung der Prüfstandsmaschinen integriert sind. Eine Versorgungseinheit speist den Zwischenkreis aus dem Hallennetz. Um vorhandene überschüssige Energie wieder in das Versorgungsnetz abgeben zu können, ist die Versorgungseinheit als aktive Netzeinheit (active front end) ausgerüstet und ermöglicht somit die sinusförmige Netzrückspeisung mit einem Leistungsfaktor 1. Die Nennleistung, 2, beträgt $260 \mathrm{~kW}$ bei netzseitiger, dreiphasiger Nennspannung von $400 \mathrm{~V}$. Der kontinuierliche Ausgangsstrom liegt bei 375 A. Die Ausgangsgleichspannung ist variabel geregelt auf 650 bis $770 \mathrm{~V}$.

Der regelbare Zwischenkreis mit einer Gleichspannung bis zu $1 \mathrm{kV}$ ist mit ausreichender Kapazität ausgestattet, um Lastschwankungen im dynamischen Prüfbetrieb zu kompensieren.

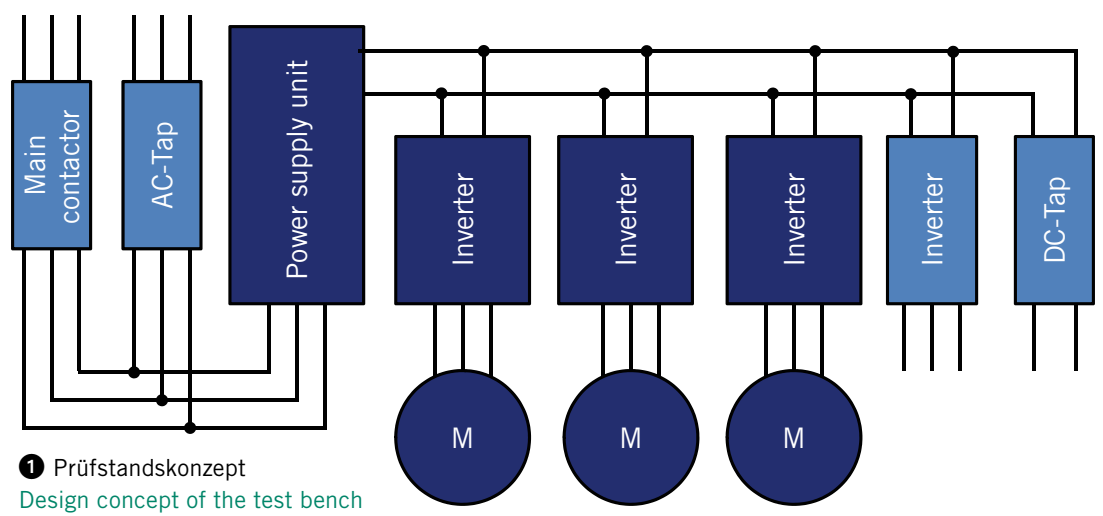




\title{
DYNAMIC TEST BENCH FOR ELECTRIC DRIVE SYSTEMS
}

\begin{abstract}
The trend towards an electrification of drive systems in mobile machines places high demands on the testing technology and its infrastructure. Especially in the area of verification of electric and hybrid electric systems the necessary test applications are getting more complex and diverse. In order to meet these requirements a dynamic propulsion system test bench was planned and put into operation at the Institute of Vehicle System Technology at the KIT. The test bench allows extensive studies of mobile propulsion systems and supports the scientific research in the field of electric and hybrid electric drive systems.
\end{abstract}

\section{MOTIVATION}

In addition to the static methods identifying individual drivetrain components, the studies of complex drive systems are in the focus of research activities. The behaviour of such systems under dynamic load is of great interest. The combination of individual subsystems in the fields of electrical, mechanical and hydraulic drivetrain technology towards interdisciplinary systems requires a powerful and substantial test bench concept. The entire test bench control architecture, with standardised interfaces for communication, has to meet high safety requirements, to guarantee an accurate test bench operation. Extensive measurement technology, with a high accuracy for the synchronous measurement of mechanical and electrical values is indispensable part of the entire test bench concept, in order to perform dynamic studies of complex electrical drive systems. The goal of a holistic systemic research approach for the study of mobile propulsion systems is fully supported by the flexibility and variability of this test bench.

\section{TEST BENCH SPECIFICATIONS}

Dynamic tests with rapid load changes require high standards to the test machines and the corresponding power electronics, to provide the necessary currents and voltages. The test bench concept, $\mathbf{1}$, is based on a DC link with integrated inverters to supply the test bench machines. A power supply unit fed the DC link with power from the grid. In order to change energy in a bidirectional way, the power supply unit is equipped with an active front end, allowing a sinusoidal regenerative feedback with a power factor of 1 . The rated power, according to, 2, is $260 \mathrm{~kW}$ at a 3 -phase voltage of $400 \mathrm{~V}$. The continuous output current is $375 \mathrm{~A}$. The output direct voltage is variable regulated from 650 to $770 \mathrm{~V}$.

The DC link with a voltage up to $1 \mathrm{kV}$ is equipped with sufficient capacity to compensate load oscillations during a dynamic test mode. High dynamics, due to the rapid change of the energy flow between the individual test machines are guaranteed. The DC link voltage also allows a maximum engine torque, to reach the field weakening of the test bench machines. Remaining energy, generated by a test bench machine, is available to other machines via the DC link.

The system composed of the DC link, the inverters and the main power supply unit is configured for the parallel operation of two test bench machines with nominal power from the grid. Three asynchronous machines are used as test bench machines, 3 . These are rated at $130 \mathrm{~kW}$ propulsion or braking power, (2). They can speed up to $5500 \mathrm{rpm}$ and can create torques up to $1000 \mathrm{Nm}$. The installed four quadrant inverters allow a highly accurate control of the machines in individual operating points up to the field weakening range of the machines. Thus they can handle both polarities, as well as a generative operation of the test equipment in both directions of rotation, output voltage and current. The rated power is $200 \mathrm{~kW}$ and can be briefly increased to $330 \mathrm{~kW}$, (2). On the output side, the inverter makes an effective rated current of $250 \mathrm{~A}$, with a peak effective output current of $425 \mathrm{~A}$ for $30 \mathrm{~s}$. The switching frequency is about $2 \mathrm{kHz}$, and $4 \mathrm{kHz}$. The output frequency is between 0 to $400 \mathrm{~Hz}$. The power inverters are liquid cooled by a central cooling system from the laboratory. An additional air cooled inverter is integrated into the DC link to provide miner power. The effective rated current is $12 \mathrm{~A}$, which can be increased to a maximum of $24 \mathrm{~A}$. A three phase output alternating voltage with a maximum of $500 \mathrm{~V}$ and a frequency range from 0 to $400 \mathrm{~Hz}$ can be provided by the inverter.

All power components are specially designed and tested. The test bench concept includes additional interfaces to deliver power. For this purpose, an alter-

AUTHORS

DIPL.-ING. CHRISTIAN POHLANDT

is Research Assistant at the Institute of Vehicle System Technology, Chair of Mobile Machines of the Karlsruhe Institute of Technology (KIT) (Germany).

DIPL.-ING. STEFAN HAAG is Research Assistant at the Institute of Vehicle System Technology, Chair of Rail System Technology of the Karlsruhe Institute of Technology (KIT) (Germany).

PROF. DR.-ING. MARCUS GEIMER is Director of the Institute of Vehicle System Technology, Chair of Mobile Machines of the Karlsruhe Institute of Technology (KIT) (Germany).

PROF. DR.-ING. PETER GRATZFELD

is Director of the Institute of Vehicle System Technology, Chair of Rail System Technology of the Karlsruhe Institute of Technology (KIT) (Germany). 


\begin{tabular}{|c|c|c|c|}
\hline \multicolumn{2}{|l|}{ 1X POWER SUPPLY UNIT } & \multicolumn{2}{|l|}{ 3X TEST BENCH MACHINES } \\
\hline Rated power & $260 \mathrm{~kW}$ & Rated power & $130 \mathrm{~kW}$ \\
\hline Rated voltage & AC $3 \times 400 \mathrm{~V}$ & Rated torque & $700 \mathrm{Nm}$ \\
\hline Output current (RMS) & $375 \mathrm{~A}$ & Rated speed & 1780 rpm \\
\hline Output voltage (DC) & $650-770 \mathrm{~V}$ & Maximum torque & $1000 \mathrm{Nm}$ \\
\hline \multirow[t]{2}{*}{ Liquid cooled } & & Maximum speed & 5500 rpm \\
\hline & & Air cooled & \\
\hline $3 \times$ INVERTER & & $1 \mathrm{x}$ INVERTER & \\
\hline Rated power & $200 \mathrm{~kW}$ & Rated power & $10 \mathrm{~kW}$ \\
\hline Max. power & $330 \mathrm{~kW}$ & Max. power & $20 \mathrm{~kW}$ \\
\hline Rated voltage (DC) & $650-770 \mathrm{~V}$ & Rated voltage (DC) & $650 \mathrm{~V}-770 \mathrm{~V}$ \\
\hline Output current (RMS) & $250 \mathrm{~A}$ & Output current (RMS) & $12 \mathrm{~A}$ \\
\hline Maximum output current (RMS) & $425 \mathrm{~A}$ for $30 \mathrm{~s}$ & Maximum output current (RMS) & $24 \mathrm{~A}$ for $30 \mathrm{~s}$ \\
\hline Switching frequency & $2 \mathrm{kHz}, 4 \mathrm{kHz}$ & Switching frequency & $2 \mathrm{kHz}, 4 \mathrm{kHz}$ \\
\hline Output frequency & $0-400 \mathrm{~Hz}$ & Output frequency & $0-400 \mathrm{~Hz}$ \\
\hline Liquid cooled & & Air cooled & \\
\hline
\end{tabular}

2 Prüfstandsspezifikation

Specification of the test bench

Eine hohe Dynamik durch die schnelle Änderung der Energieflüsse zwischen den einzelnen Prüfstandsmaschinen ist folglich gewährleistet. Die hohe Zwischenkreisspannung ermöglicht es zudem, maximale Motordrehmomente im Feldschwächbereich der Prüfstandsmaschinen anzufahren. Außerdem steht die über den Zwischenkreis in generatorischen Betriebspunkten erzeugte Leistung einer Prüfstandsmaschine anderen Maschinen zur Verfügung.
Der Prüfstand ist projektiert auf den Betrieb zweier Belastungsmaschinen mit Nennleistung aus dem Versorgungsnetz. Als Prüfstandsmaschinen kommen drei Asynchronmotoren zum Einsatz, 3. Diese stellen dauerhaft eine Antriebsoder Bremsleistung von $130 \mathrm{~kW}$ bereit, (2). Es können Drehzahlen bis maximal 5500/min und Drehmomente bis 1000 $\mathrm{Nm}$ angefahren werden. Die eingebauten Wechselrichter erlauben eine hochgenaue Ansteuerung einzelner Betriebs-

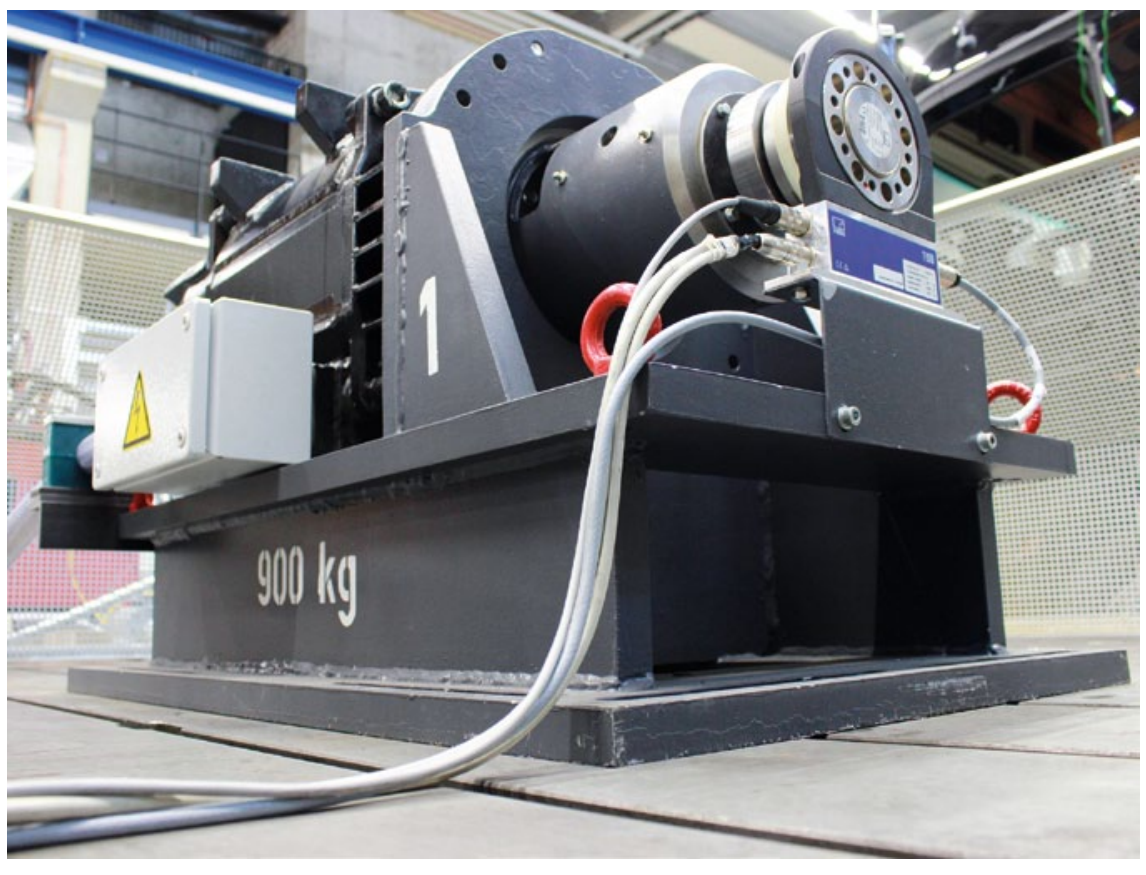

(3) Prüfstandsmaschine mit Drehmomentmesswelle Test bench machine with adapted torque transduce

\section{Raus aus dem}

\section{Messdaten-Dschungel!}
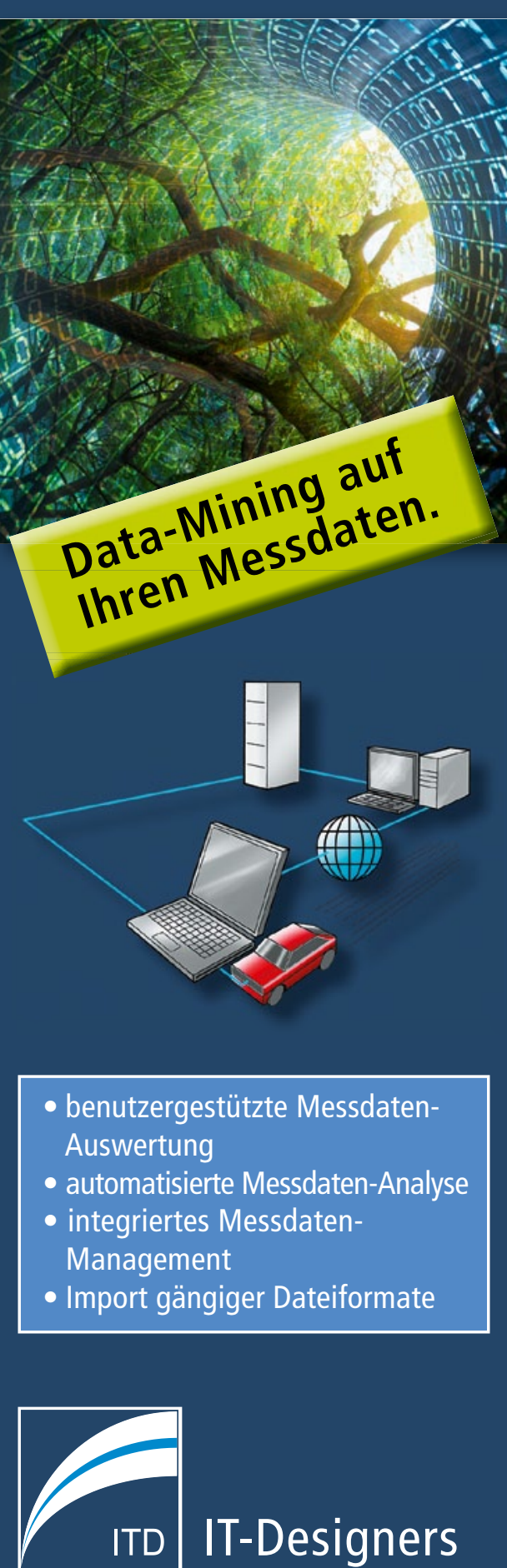

\section{IT-Designers}

Entennest 2 - D - 73730 Esslingen Fon 0711 / $305111-50$ www.it-designers. de info@tedradis.de 
nating voltage tap is mounted before the main power supply unit, which provides a three phase voltage of $400 \mathrm{~V}$ at $50 \mathrm{~Hz}$. Another direct voltage tap allows a power pick off at the DC link. An integrated temperature and safety monitoring is included in all installed components. The control functionalities of the individual inverters allow a specific speed and torque limiting, as well as a directional limiting. The operation of rotary and linear actuators is possible in general. An internal voltage and current supervisor board monitors critical conditions during dynamic operation. Acceleration and deceleration ramps can be implemented and separately adjusted to directly influence the dynamics. The individual inverters are equipped with a multi-stage safety concept according to safety integrity level (SIL) 3. The entire power distribution enclosure, 4, is also equipped with broad safety equipment.

The test bench control allows a precise control of the system and ensures a safe test operation. It is controlled via an external control unit with graphical user interface. A reference input variable can be made by a touchpad via manual input. Individual potentiometers for each inverter enable a separate reference input variable to the test bench machines by a manual operation mode. Another reference input can be done by external specification of analogous signals via corresponding transducers in the range of $\pm 10 \mathrm{~V}$. The individual inverters and the main power supply unit can be further controlled via the graphical user interface, to set approvals or restrictions. Thus, an individual operation of inverters for various test applications is guaranteed.

Several measuring instruments to analyse mechanical, electrical and thermal quantities are part of the propulsion system test bench. The transducers measure torques at $200 \mathrm{Nm}$ or $1000 \mathrm{Nm}$ with optional speeds up to $20,000 \mathrm{rpm}$ and are equipped with appropriate overload capacity. For detection of electrical measurement values, a high-precision power meter is used. It captures eight channels time-synchronous, enabling a comprehensive data analysis of electrical variables. Therefore, it can be detected for power calculation consequently eight voltage values and eight current values. The voltage range is up to $1000 \mathrm{~V}$. By the use of accurate converters maximum currents up to 400 A can be measured. The time-synchronous measuring of mechanical and electrical values is given. Thus the measuring capabilities meet a key requirement for analysing hybrid electric drive systems.

The test bench design presupposes a torsionally stiff and slip-free mechanical connection between a test bench machine and the device under test, in order to derive the dynamic loads directly and without any delay. Therefore the test bench machines are designed as direct drives. A standardised shaft height of $450 \mathrm{~mm}$ applies to the entire test bench machines. Two clamping plates with dimensions $4 \mathrm{~m}$ x $5 \mathrm{~m}$ allow a variable positioning of individual test devices. This could be single components as well as entire vehicles. The flexible handling of the test bench machines allow an incorporation of transmission gears for speed and torque adjustment. Also the measuring equipment can be customised in accordance with the required measuring range. Thus, for example, the torque measuring shafts can be exchanged to increase the measuring accuracy. The power electronics and the controls are located directly to the test bench to be able to use short cables and a direct power tap on the inverters. So it is also possible to test components like self-developed linear drives and motors using the existing inverters.

\section{INFRASTRUCTURE}

The entire propulsion system test bench, 5, is build up in an experimental laboratory with extensive infrastructure. Several mechanical and electrical workshops are located nearby the laboratory to maintain and prepare a test device. Two doors enable the double-sided test bench accessibility via forklift. For a safe handling of heavy equipment, the laboratory is equipped with a 20 ton overhead crane. The arrangement of the clamping plates provides enough space for further power supply units and equipment like batteries or supercapacitors to be placed. A fume extraction is available to test conventional and hybrid drivetrain topologies, also a separate cooling system for test devices.

The communication infrastructure on the test bench enables the usage of typical vehicle interfaces to apply load and driving profiles. The different systems can be addressed via CAN and allow an automatic test mode. The test bench is embedded with a virtual simulation environment that allows investigation of innovative drive systems in virtual test drives by means of real-time control hardware. Thus, the established hardware-in-the-loop test environment is characterised by a high reproducibility under defined environmental conditions and permits field applications to be transferred directly to the test bench.

\section{SYSTEM APPLICATIONS}

The three test bench machines enable studies on single drive system components, complex subsystems up to entire vehicles, 6. Individual components, such as electrical machines, $\mathbf{7}$, or axes can be measured and analysed. Corresponding to the measuring ranges, the transducers can be customised. Also the required speed and torque ranges can be adjusted using gears. Additionally subsystems and complete drive systems can be analysed, which can be variable positioned on the clamping plats. Innovative drive system topologies are hereby examined and individual prototypes in the drive system can be tested individually by exchanging defined subsystems. The test bench also allows testing of electric drive systems to analyse different motors, inverters and batteries under dynamic behaviour. This approach is supported by the measurement equipment, which allows electrical and mechanical parameters to be measured synchronously, $\mathbf{8}$. The usage of multiple test bench machines enables the measurement of complete drivetrains in a conventional or hybrid structure. Likewise, complete battery-electric drivetrains can be tested. The dimensions of the clamping plats, including the test equipment and the existing infrastructure, allow the assembly of vehicles, such as municipal vehicles and light trucks. The torque is applied directly on the wheel shafts. A slip-dependent wheel-roller contact, as required in a chassis dynamometer, is not necessary.

\section{TEST SCENARIOS}

The modular design of the drive system test bench makes it possible to build up a wide variety of test applications at the 


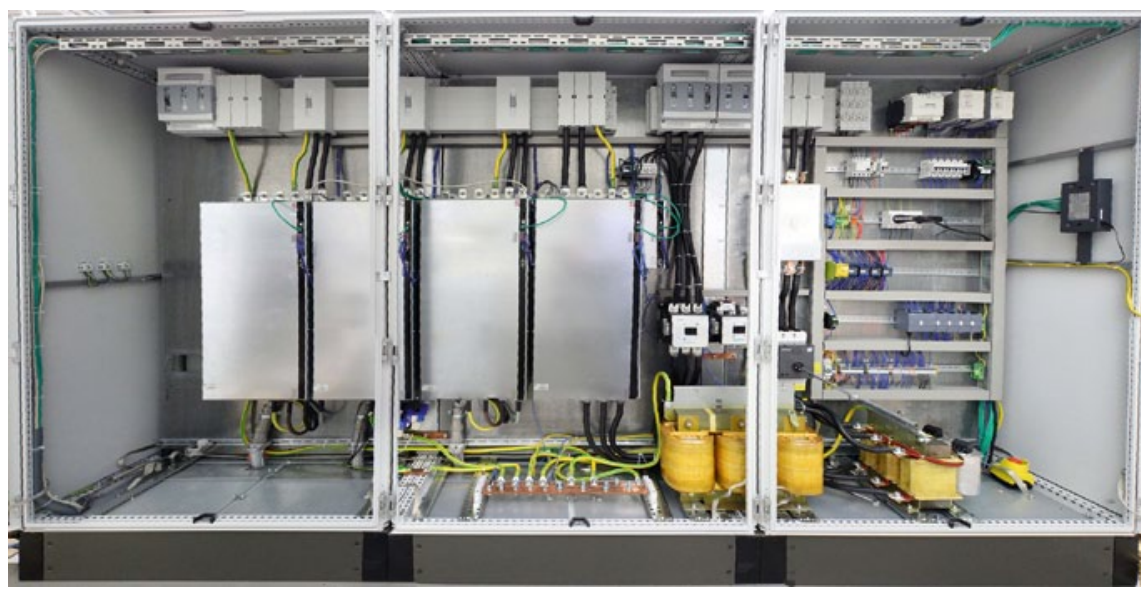

punkte bis in den Feldschwächbereich und sind als Vier-Quadranten-Steller ausgeführt. Ausgangsspannung und Ausgangsstrom vermögen dadurch beide Polaritäten anzunehmen, wodurch sowohl ein motorischer, wie auch generatorischer Betrieb der Prüfstandsmaschinen in beiden Drehrichtungen realisiert werden kann. Die Nennleistung liegt bei $200 \mathrm{~kW}$ und kann kurzzeitig auf bis zu $330 \mathrm{~kW}$ erhöht werden, (2). Ausgangsseitig stellen die Wechselrichter dauerhaft einen effektiven Bemessungsstrom von 250 A bereit und können mit einem effektiven Spitzenausgangsstrom von 425 A für $30 \mathrm{~s}$ belastet werden. Die Schaltfrequenz liegt bei $2 \mathrm{kHz}$, beziehungsweise $4 \mathrm{kHz}$. Die Ausgangsfrequenz liegt dabei zwischen 0 bis $400 \mathrm{~Hz}$. Die Wechselrichter sind flüssigkeitsgekühlt und werden von einer zentralen Hallenkühlung gespeist, wodurch eine direkte Anreihung in der Schaltanlage möglich ist. Zur Bereitstellung geringerer Leistungen ist ein weiterer Wechselrichter in den Zwischenkreis integriert. Dieser ist luftgekühlt ausgeführt und ebenso anreihbar. Der Wechselrichter stellt ausgangsseitig einen effektiven Bemessungsstrom von 12 A bereit, der kurzzeitig auf maximal 24 A erhöht werden kann. Die dreiphasige Ausgangswechselspannung liegt bei maximal $500 \mathrm{~V}$ mit einer Frequenz von 0 bis $400 \mathrm{~Hz}$.

Alle leistungselektronischen Komponenten sind Sonderbauformen und werkseitig aufeinander abgestimmt. Das Prüfstandskonzept beinhaltet weitere Schnittstellen, um Leistungen abgreifen zu können. Hierzu ist ein Wechselspannungsabgriff vor der Versorgungseinheit eingebaut, der eine dreiphasige Spannung

von $400 \mathrm{~V}$ bei $50 \mathrm{~Hz}$ zur Verfügung stellt. Ein weiterer Gleichspannungabgriff ermöglicht es, direkt in den Zwischenkreis eingreifen zu können. Alle verbauten Komponenten verfügen über
Passion. Innovation. Solutions.

\section{Powertrain Development}

\section{INDUSTRIAL ENGINES}

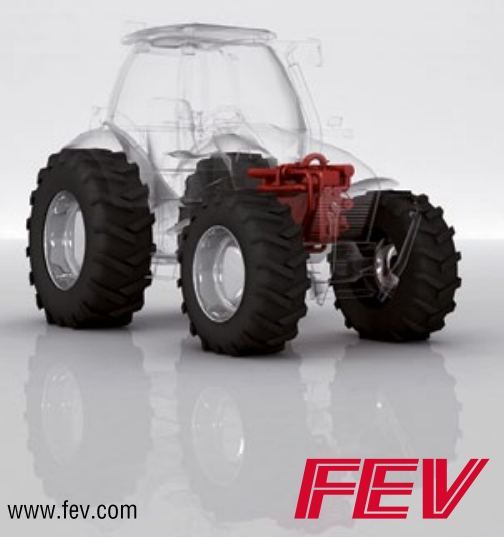

eine integrierte Temperatur- und Sicherheitsüberwachung. Die hinterlegten Regelungen der einzelnen Wechselrichter ermöglichen eine gezielte Drehzahlund Drehmoment- sowie eine Richtungsbegrenzung. Der Betrieb von rotatorischen und linearen Aktuatoren ist grundsätzlich möglich. Durch eine interne Spannungs- und Stromüberwachung werden kritische Zustände im
(4) Schaltanlage mit Wechselrichtern und Versorgungseinheit Enclosure and power distribution fed by power supply unit and inverters

dynamischen Betrieb sofort detektiert. Mittels separater Vorgabe von Beschleunigungs- und Verzögerungsrampen kann direkt in die Dynamik eingegriffen werden. Die einzelnen Wechselrichter sind mit einem mehrstufigen Sicherheitskonzept gemäß dem Sicherheitsintegritätslevel (SIL) 3 ausgestattet. Die gesamte Schaltanlage, 4, ist zusätzlich mit zentralen und dezentralen Sicherheitsausrüstungen ausgestattet.

Eine umfangreiche Prüfstandssteuerung erlaubt die präzise Ansteuerung der gesamten Anlage und garantiert einen sicheren Prüfstandsbetrieb. Die Steuerung erfolgt über ein externes Bedienterminal mit graphischer Bedienoberfläche. Eine Sollwertvorgabe kann mittels manueller Eingabe per Touchpad erfolgen. Einzelne Drehpotenziometer für jeden Wechselrichter ermöglichen eine Sollwertvorgabe im individuellen Handbetrieb der Prüfstandsmaschinen. Eine weitere Sollwertvorgabe kann durch eine externe Vorgabe von analogen Signalen über entsprechende Messwandler im Bereich von $\pm 10 \mathrm{~V}$ erfolgen. Die einzelnen Wechselrichter und die zentrale Versorgungseinheit können des Weiteren über die graphische Bedienoberfläche angesteuert werden, um Freigaben oder Beschränkungen zu setzen. Somit ist ein gezielter Einzelbetrieb der Wechselrichter für unterschiedliche Prüfapplikationen gewährleistet.

Ein umfassendes Messsystem zur Erfassung mechanischer, elektrischer und thermischer Größen ist Bestandteil des Antriebssystemprüfstands. Die Messwellen erfassen Drehmomente von $200 \mathrm{Nm}$ oder wahlweise $1000 \mathrm{Nm}$, mit Drehzahlen bis zu 20.000/min und entsprechender Überlastfähigkeit. Zur Erfassung elektrischer Messgrößen wird ein Hochpräzisions-Leistungsmessgerät verwendet. Es ist in der Lage, acht Kanäle zeitsynchron zu erfassen und ermöglicht dadurch eine umfassende Messdatenauswertung elektrischer Größen. Es können folglich acht Spannungsgrößen und acht Stromgrößen zur Leistungsberechnung erfasst werden. Der Spannungsbereich liegt bei bis zu 1000 V. Durch die Ver- 


\section{MEASURING TECHNIQUES}

component and system level in a safe test environment. At the component level the development of simulation models and the design of controllers are in the focus of research activities. The existing measurement technology enables static power measurements on electrical and mechanical components for the determination of efficiency maps, 9. An automated testing of electrical machines is also possible with the test bench control, as well as the examination of causeeffect interactions, such as the relationship between the variation of the air gap of an electric linear actuator and the achievable forces. By studying the thermal behaviour of electrical machines under dynamic loads, the development of thermal management strategies in electric drive systems is also enabled.

On a system level, driving and operating strategies of vehicles can be tested and evaluated. The test bench allows the static and dynamic analysis of propul- sion systems under defined and reproducible conditions using a virtual simulation environment. This hardware-inthe-loop simulation, for example, functional tests of ECUs and testing of algorithms for driver assistance systems are applicable test scenarios. Supported by the simulation tools, a comprehensive variant testing, by varying parameters and replacing components, is quite possible. Especially in the field of future electric mobility, research activities for the energy efficiency of different drive system topologies are focused.

\section{SUMMARY}

The Institute of Vehicle System Technology designed and put a dynamic propulsion test bench into action, to complement existing test capabilities and support the holistic systemic research. In order to understand the system behaviour of future electrical drive systems, first of all the understanding of individual system components needs to be documented. Static tests provide the necessary information for conceptual system design studies. The test bench with its measurement technology provides the data base for this purpose. Field test data can be transferred directly to the test bench in order to examine the behaviour of propulsion systems under dynamic loads with the implemented virtual simulation. From the individual component of the propulsion system to subsystems and the entire vehicle, the dynamic propulsion test bench provides important measurement data and supports the research activities in the field of electric propulsion systems for future mobility.

\section{REFERENCE}

[1] Pohlandt, C.; Haag, S. et al.: Modeling of hybrid and electric powertrain components considering additional losses. Research Report, German Research Association for Drive Technology, Frankfurt, 2013 


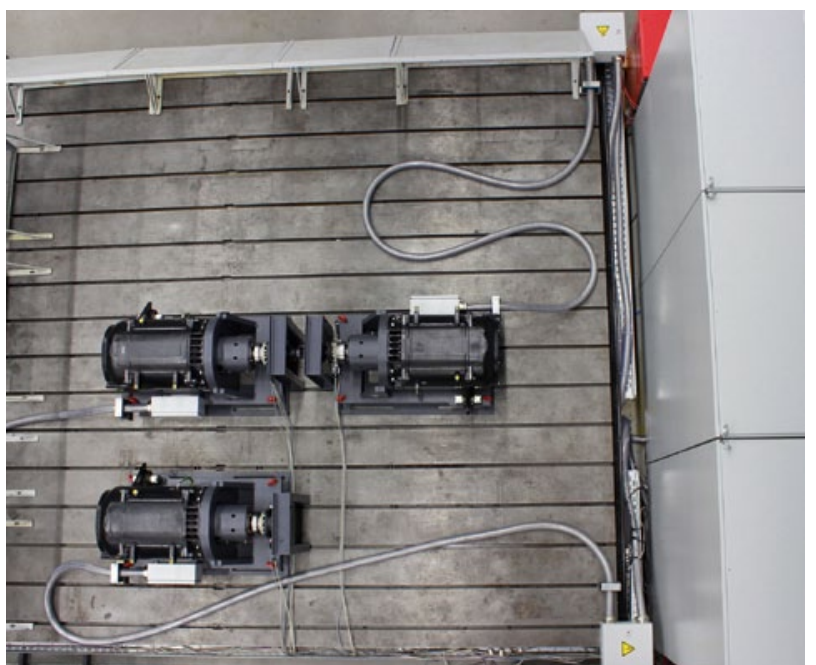

(5) Antriebssystemprüfstand Dynamic propulsion test bench

wendung von Präzisionsumsetzern sind maximale Ströme bis zu 400 A erfassbar. Die zeitsynchrone Erfassung mechanischer und elektrischer Messgrößen ist dabei gegeben. Der Prüfstand erfüllt damit eine zentrale Anforderung zur Untersuchung hybridelektrischer Antriebssysteme.
Das Prüfstandskonzept setzt eine drehsteife und schlupffreie mechanische Verbindung zwischen Prüfstandsmaschinen und den Prüflingen voraus, um die dynamischen Belastungen direkt und ohne Verzögerungen in den Prüfling leiten zu können. Diese Anforderung wird durch die Auslegung der Prüfstandsmaschinen als Direktantriebe mit entsprechenden Gelenkwellen zur Prüflingsanbindung ermöglicht. Dabei gilt eine einheitliche Wellenhöhe von $450 \mathrm{~mm}$ auf dem gesamten Prüfstand. Zwei gedämpft aufgestellte Spannplatten mit den Abmaßen $4 \mathrm{~m} \times 5 \mathrm{~m}$ erlauben die variable Positionierung einzelner Prüflinge bis hin zu gesamten Fahrzeugen. Das flexible Handling auf dem Prüfstand erlaubt darüber hinaus einen Einbau von Getrieben zur Drehzahl- und Drehmomentanpassung. Auch lässt sich das eingesetzte Messequipment entsprechend den geforderten Messbereichen anpassen. So können beispielsweise die Drehmomentmesswellen zur Erhöhung der Messgenauigkeit ausgetauscht wer-

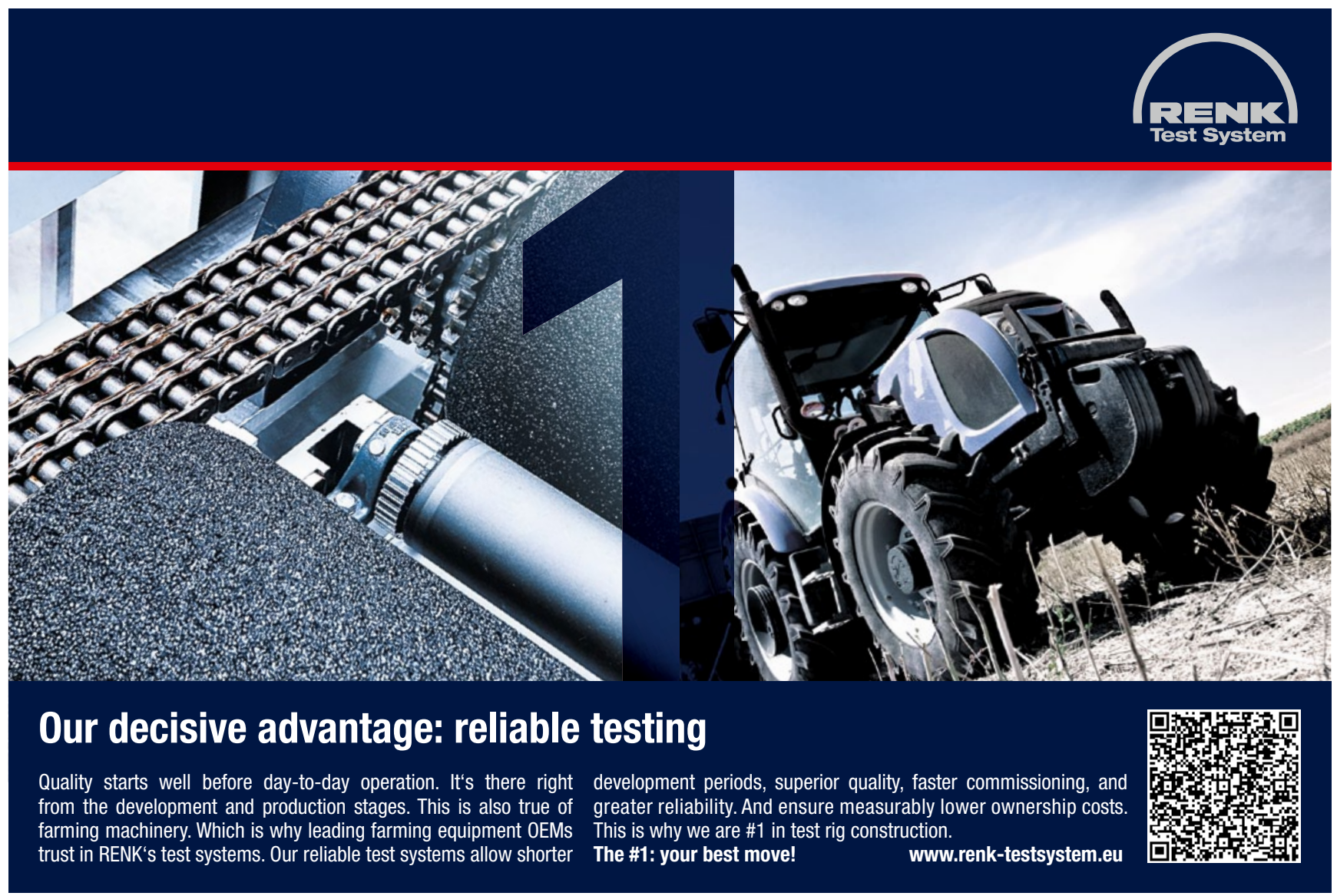




\begin{tabular}{|c|c|}
\hline TEST CATEGORY & EXAMPLE OF APPLICATION \\
\hline Component & $\begin{array}{l}\text { Electric machine } \\
\text { Gearbox } \\
\text { Combustion engine } \\
\text { Axle }\end{array}$ \\
\hline Sub-system & $\begin{array}{l}\text { Electric machine inverter battery } \\
\text { Gearbox with mounted axle } \\
\text { Combustion engine with mounted gearbox } \\
\text { Electric axle }\end{array}$ \\
\hline Propulsion system & $\begin{array}{l}\text { Powertrain } \\
\text { Diesel electric powertrain } \\
\text { Battery electric powertrain } \\
\text { Hybrid powertrain } \\
\end{array}$ \\
\hline Vehicle & $\begin{array}{l}\text { Forklift } \\
\text { Municipal vehicle } \\
\text { Compact loader } \\
\text { Tractor }\end{array}$ \\
\hline
\end{tabular}

Systemapplikationen System applications den. Die zugehörige Schaltanlage mit der Leistungselektronik und die Prüfstandssteuerung sind direkt am Maschinenbett angeordnet. Die kurzen Leitungswege ermöglichen somit einen direkten Leistungsabgriff an den Wechselrichtern der Schaltanlage. Dadurch können Komponenten, wie zum Beispiel eigenentwickelte Linearantriebe und Motoren, an den vorhandenen Wechselrichtern getestet werden.

\section{INFRASTRUKTUR}

Der gesamte Antriebssystemprüfstand, 5, ist in einer Versuchshalle mit umfangreicher Infrastruktur untergebracht. Neben Rüstarbeitsplätzen sind mechanische und elektrische Werkstätten in der Halle angesiedelt. Der Zugang zum Prüfstand erfolgt über zwei Hallentore, die es ermöglichen, die Spannbetten von zwei Seiten anzufahren. Die Montage kleinerer Prüflinge kann so per Stapler erfolgen. Zum sicheren Bewegen schwerer Prüflingslasten verfügt die Halle über einen 20-t-Zweiträgerlaufkran. Die räumliche Anordnung der Spannbetten bietet ausreichend Stellfläche, um gegebenenfalls weitere Schaltanlagen für eine Testapplikation zu installieren. Zur Untersuchung konventioneller und hybrider Antriebstopologien steht in der Versuchshalle eine Rauchgasabsaugung zur Verfügung. Außerdem ist der Prüfstand mit einem separaten, regelbaren Kühlkreislauf zur Kühlung von Prüflingen ausgestattet.

Die Kommunikationsinfrastruktur am Prüfstand ermöglicht über die fahrzeugtypischen Schnittstellen definierte Lastund Fahrprofile vorzugeben. Die unterschiedlichen Systeme lassen sich flexibel per CAN ansprechen und erlauben einen automatischen Prüfbetrieb. Des Weiteren ist der Prüfstand in eine virtuelle Simulationsumgebung eingebettet, die mittels echtzeitfähiger Steuerungshardware die

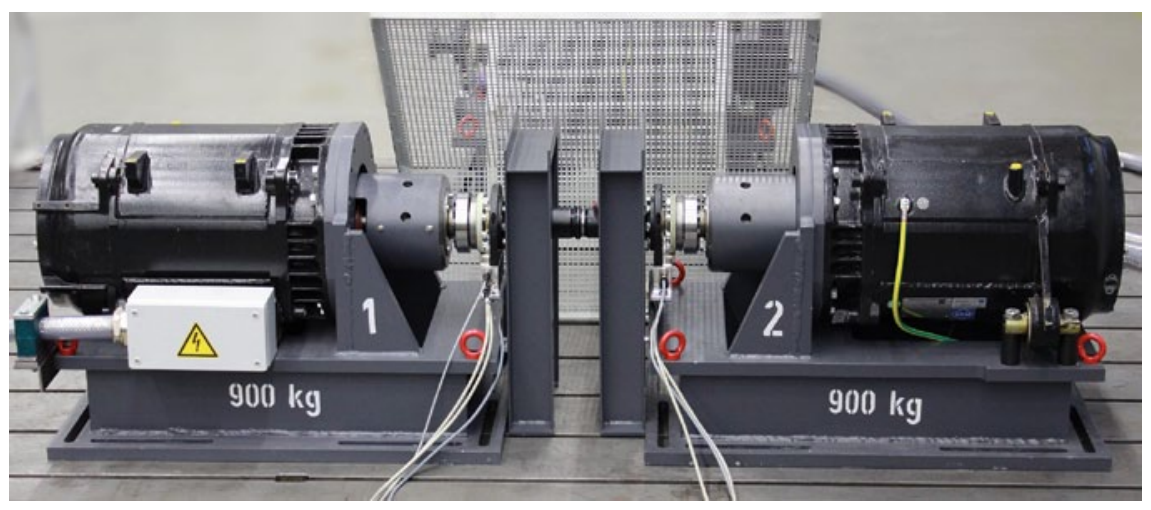

Vermessung einer elektrischen Maschine auf dem Prüfstand Automated testing of an electric machine
Untersuchungen innovativer Antriebssysteme in virtuellen Fahrversuchen ermöglicht. Die so geschaffene Hardware-in-the-Loop-Testumgebung zeichnet sich durch eine hohe Reproduzierbarkeit unter definierten Umgebungsbedingungen aus und erlaubt es, diverse Feldapplikationen direkt auf den Prüfstand zu übertragen.

\section{SYSTEMAPPLIKATIONEN}

Durch die drei frei konfigurierbaren Prüfstandsmaschinen ermöglicht der Prüfstand Untersuchungen an einzelnen Antriebssystemkomponenten, komplexen Teilsystemen bis hin zu gesamten Fahrzeugen, 6. Es können einzelne Komponenten, wie elektrische Maschinen, $\boldsymbol{\boldsymbol { \tau }}$, oder Achsen vermessen werden. Die vorhandene Messtechnik erlaubt die individuelle Anpassung entsprechender Messbereiche. Auch lassen sich geforderte Drehzahl- und Drehmomentbereiche durch den Einsatz von Getriebestufen anpassen. Durch die Verwendung weiterer Prüfstandsmaschinen lassen sich komplette Teilantriebssysteme untersuchen, welche flexibel auf den Spannbetten positioniert werden können. Komplette Antriebstopologien können hiermit untersucht werden und einzelne Prototypen im Antriebssystem, durch den Austausch von Teilsystemen, getestet werden. So ermöglicht es der Prüfstand im Bereich der elektrischen Antriebssysteme unterschiedliche Motoren, Wechselrichter und Batterien im dynamischen Verhalten des gesamten Antriebssystems zu untersuchen. Unterstützt wird dieses Vorgehen durch die umfangreiche Messtechnik, welche es erlaubt, elektrische und mechanische Messgrößen zeitsynchron zu erfassen, 8. Die mechanische Einspannung durch Verwendung mehrerer Prüfstandsmaschinen ermöglicht es, vollständige Antriebsstränge in konventioneller oder hybrider Struktur zu untersuchen. Ebenso lassen sich komplette batterieelektrische Antriebsstränge testen. Die Abmaße der Spannbetten, inklusive der Prüfstandsmaschinen und die vorhandene Infrastruktur gestatten darüber hinaus die Montage von Fahrzeugen, wie Kommunalfahrzeugen und Staplern. Die Drehmomenteinleitung erfolgt dabei direkt über die Radnaben. Ein schlupfabhängiger Rad-Rollenkontakt mit etwaigen Niederzugeinrichtun- 
gen, wie bei Rollenprüfständen erforderlich, entfällt dabei.

\section{TESTSZENARIEN}

Der modulare Aufbau des Antriebssystemprüfstands ermöglicht es, verschiedenste Testapplikationen auf Komponenten- und Systemebene aufzubauen und in einer abgesicherten Testumgebung zu untersuchen. Auf der Komponentenebene stehen die Entwicklung von Simulationsmodellen und die Auslegung von Reglern im Fokus der Aktivitäten. Die vorhandene Messtechnik ermöglicht statische Leistungsmessungen an elektrischen und mechanischen Komponenten zur Ermittlung von Kennfeldern für die Modellerstellung und -validierung, 9. Mit dem Prüfstand ist die automatisierte Durchführung von Maschinenprüfungen an elektrischen Maschinen ebenso wie die Untersuchung von Wirkzusammenhängen umsetzbar, wie zum Beispiel die Untersuchung des Zusammenhangs zwischen der Variation des Luftspalts eines elektrischen Linearaktuators und der erzielbaren Kräfte. Durch die Untersuchung des thermischen Verhaltens elektrischer Antriebe wird ein gezieltes Thermomanagement in elektrischen Antriebssystemen unter dynamischen Belastungen realisierbar.

Auf Fahrzeugsystemebene können Fahr- und Betriebsstrategien untersucht werden. Der Prüfstand erlaubt die statische und dynamische Untersuchung von Antriebssystemen unter definierten reproduzierbaren Umgebungseinflüssen durch die Verwendung einer virtuellen Umgebung. Mittels dieser Hardware-inthe-Loop-Umgebung können beispielsweise Funktionsprüfungen an Steuergeräten und Tests von Algorithmen für Fahrerassistenzsysteme durchgeführt werden. Unterstützt durch eine Simulationsumgebung kann durch Parametervariation und Austausch von Komponenten eine umfassende Variantenprüfung stattfinden. Gerade im Anwendungsgebiet der Elektromobilität lassen sich Untersuchungen zur Energieeffizienz verschiedener Antriebstopologien durchführen.

\section{ZUSAMMENFASSUNG}

Der am Karlsruher Institut für Fahrzeugsystemtechnik konzipierte und in Betrieb genommene Antriebssystemprüfstand ergänzt die bereits vorhandenen Prüf-

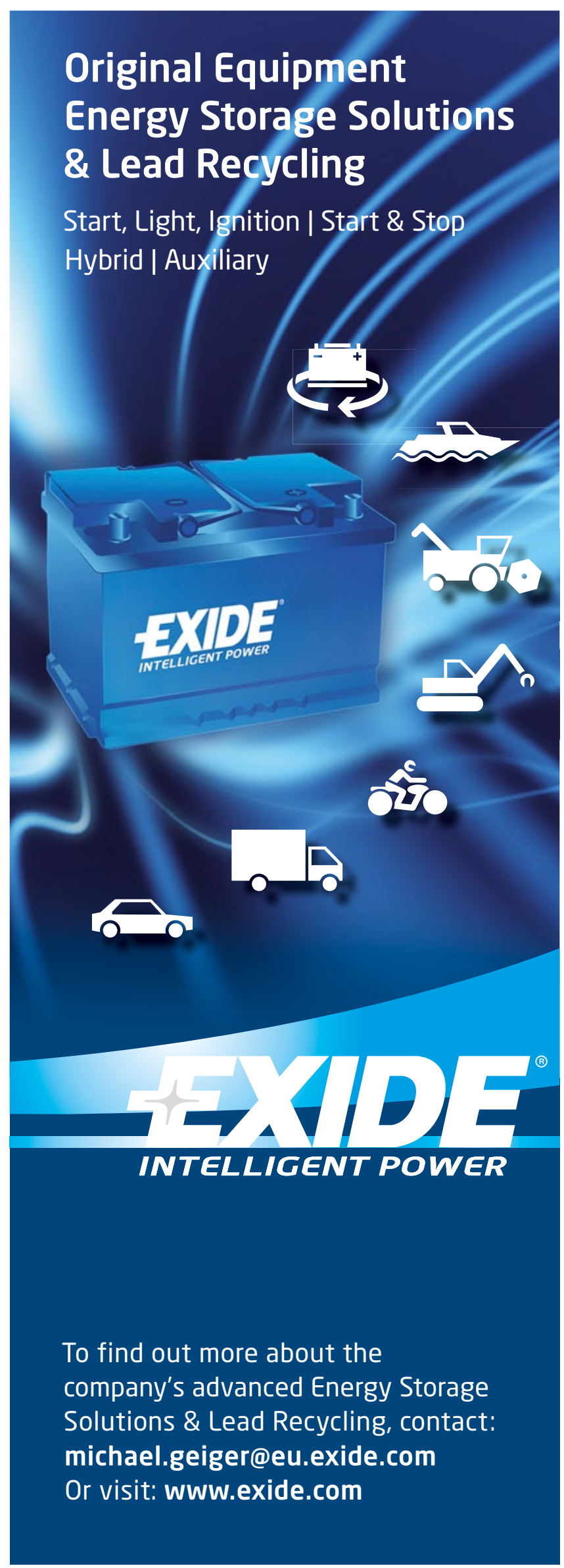




\section{SEIT 75 JAHREN AM MOTORTECHNISCHEN PULS DER ZEIT.}

\section{WIR FEIERN GEBURTSTAG!}

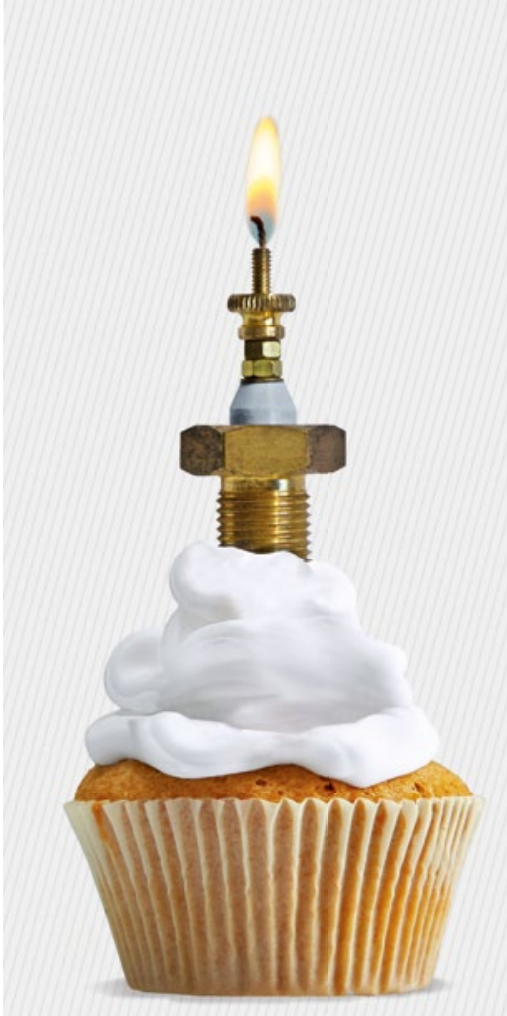

Seit 75 Jahren beleuchtet die MTZ Motortechnische Zeitschrift Monat für Monat die bewegendsten Themen der Welt: den Verbrennungsmotor und andere Antriebe. Dabei hat unser Geburtstagskind das Wunder vollbracht, in Aufmachung und Inhalt immer jung zu bleiben. Und in einem Punkt ist die MTZ sich stets treu geblieben: in dem Anspruch ihren Lesern qualitativ hochwertigen Fachjournalismus zu bieten. www.springerprofessional.de/mtz

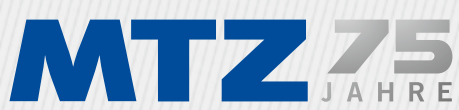

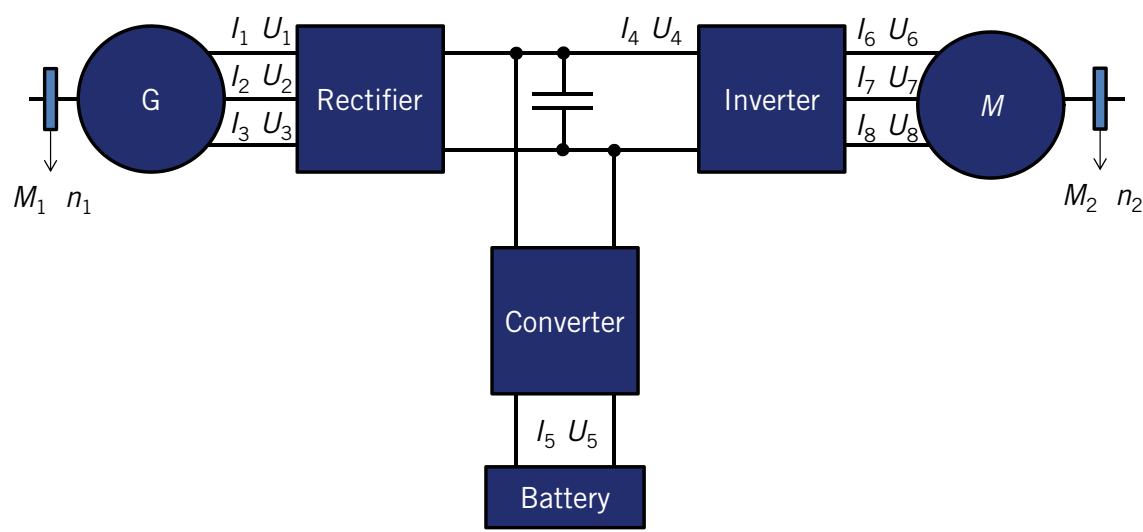

8 Messstellenplan zur Leistungsmessung an einem elektrischen Antriebsstrang Measurement setup to analyse an electric drivetrain

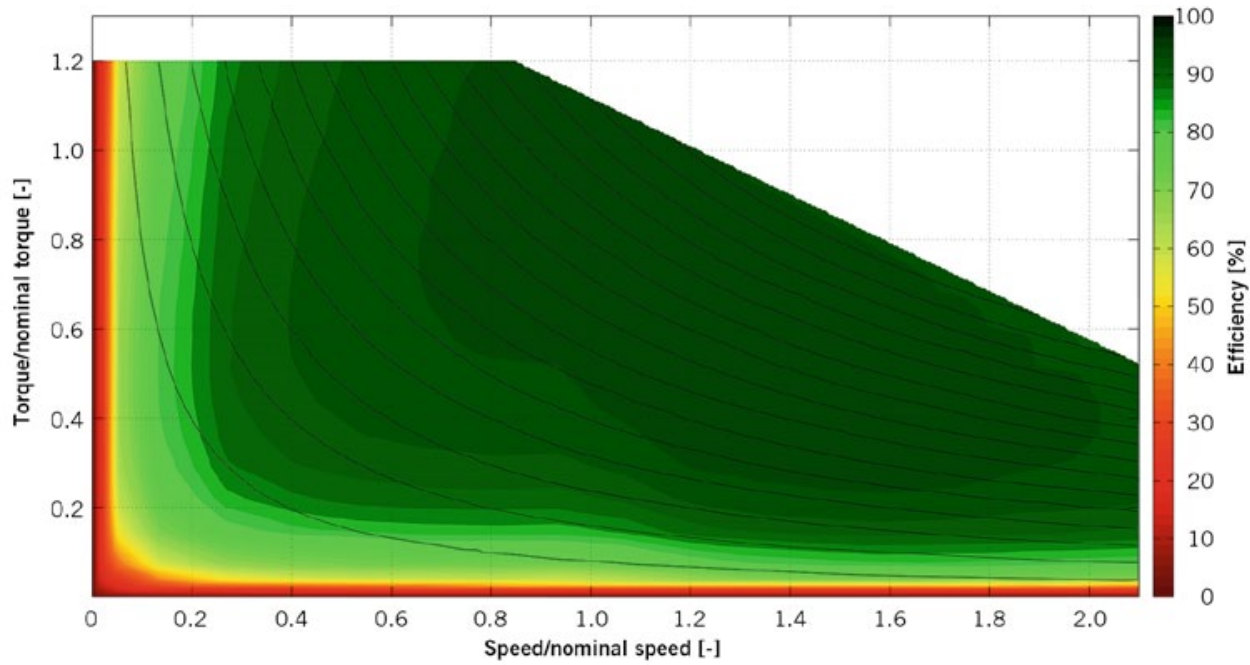

9 Auf dem Prüfstand ermitteltes Wirkungsgradkennfeld einer elektrischen Maschine [1] Measured efficiency map for an electric machine [1]

stände und unterstützt den ganzheitlich systemischen Forschungsansatz. Um das Systemverhalten heutiger und zukünftiger elektrischer Antriebssysteme zu verstehen, bedarf es zuallererst dem eingehenden Verständnis der Systemkomponenten. Statische Versuche liefern hier die notwendigen Anhaltspunkte für die konzeptionelle Systemauslegung. Der Prüfstand mit seiner umfangreichen Messtechnik liefert hierzu die entsprechende Datengrundlage. Im Feldversuch gewonnene Messdaten können mittels vorhandener virtueller Umgebung direkt auf den Prüfstand übertragen werden, um das Verhalten von Antriebssystemen unter dynamischen Lasten zu untersuchen. Von der einzelnen Komponente im Antriebssystem, über Teilsysteme bis hin zum gesamten Fahrzeug liefert der
Prüfstand wichtige Messdaten und unterstützt die Forschungsaktivitäten im Bereich elektrischer Antriebssysteme für zukünftige Mobilitätsansätze.

\section{LITERATURHINWEIS}

[1] Pohlandt, C.; Haag, S. et al.: Modellbildung verlustbehafteter hybrider, elektrischer Antriebsstrangkomponenten. FVA-Forschungsheft, Forschungsvereinigung Antriebstechnik, Frankfurt, 2013 